\title{
Gender Analysis in Indonesia's Legislation Regarding Political Laws
}

\author{
Erlina \\ Universitas Lambung Mangkurat, Indonesia \\ erlina@ulm.ac.id \\ Nika Normadilla \\ Universitas Lambung Mangkurat, Indonesia \\ abaurizky123@gmail.com
}

\begin{abstract}
This paper examines Indonesia's current legislation on politics, inter alia, Political Parties Law, Election Law, and Parliament Law. By using gender analysis, this paper considers how these laws ensure equitable access, participation, control, and benefits for men and women. Under the justice and gender equality approach, this paper considers that these laws are not optimal, especially under the control and benefits indicators. In this context, Political Parties Law contributes more to the indicator of access. Simultaneously, Electoral Law provides access and participation indicators. Parliament Law is expected to contribute the most to the control and benefits indicators. However, it is regrettable that Parliament Law does not comply with these two indicators. The Constitutional Court's interpretation was not followed in a series of legislative revisions of Parliament Law. Therefore, the gender approach in the legislative revision of these three laws should be encouraged to benefit from social life with more just and non-discriminatory. It should also provide equal opportunity for every citizen to gain access, participatory rights, control, and development benefits. Hence, it is inevitable to the importance of the government commitment in gender mainstreaming in policy, harmonization, and synchronization of laws and regulations.
\end{abstract}

KEYWORDS: Gender Justice and Equality, Political Laws, Women's Representation.

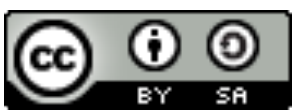

Copyright $\odot 2020$ by Author(s)

This work is licensed under a Creative Commons Attribution-ShareAlike 4.0 International License. All writings published in this journal are personal views of the authors and do not represent the views of this journal and the author's affiliated institutions.

\section{HOW TO CITE:}

Erlina \& Nika Normadilla. “Gender Analysis in Indonesia’s Legislation Regarding Political Laws” (2020) 7:3 Lentera Hukum 337-354.

Submitted: October 10, 2020 Revised: November 1l, 2020 Accepted: November 19, 2020 


\section{INTRODUCTION}

Indonesia was ranked 85 out of 153 countries in the 2020 Global Gender Gap Index. ${ }^{1}$ This figure remained from 2018. This ranking asserts that Indonesia is still far behind neighboring countries, such as the Philippines, Laos, Singapore, and Thailand, respectively at $16,43,54$, and $75 .^{2}$ From this ranking, it is essential to note that the Philippines has consistently reduced gender inequality by optimizing economic and political leadership for women and men. ${ }^{3}$ One of the indicators in the preparation of the biennial report is women's political participation. The women's representation in the 2019 Indonesian Election increased from 17.9\% in the 2014 Election to 20.3\% in the 2019 Election. ${ }^{4}$ However, it did not reach $30 \%$ of the allotted representation. ${ }^{5}$ This percentage becomes the minimum figure for women to influence the formation of gender-equitable regulations and budgeting significantly.

The Organization for Economic Cooperation and Development (OECD) emphasizes the importance of parliament's role in implementing the gender equality agenda. The OECD states that parliaments and legislative bodies are the core actors in realizing the gender equality agenda in their capacities as lawmakers, supervisory bodies, and employers. As people's representatives, parliaments are expected to reflect the gender's demands and needs they represent. They also must ensure all policies, particularly legislative outputs, to accommodate their interests. Besides, these actors must ensure equal opportunities for women and men in realizing their potential fully. This effort provides conditions for parliaments and legislatures to emulate and promote gender sensitivity in all processes, practices, and procedures. ${ }^{6}$ In contrast, the House of Representatives in Indonesia does not reflect an equal number of women and men. The leadership does not support reserved women.

Women's position in the parliamentary structure influences the struggle for gender-just policies and budgeting. The guarantee for women in obtaining a strategic position in parliament is not accommodated in the Law on the People's Consultative Assembly, the People's Representative Council, the Regional Representative Council, and the Regional People's Representative Council (Parliament Law). The removal of the clause on women's representation in the Parliament Law is contrary to existing laws, and

\footnotetext{
World Economic Forum, Global Gender Gap Report 2020 (2019) at 9.

Ibid.

Ibid.

Tirto.id, "Isi Kursi DPR 2019-2024, Porsi Perempuan Meningkat", online: ‘https://tirto.id/isi-kursidpr-2019-2024-porsi-perempuan-meningkat>.

5 House of Representatives, “Isu Gender Akan Diperjuangkan,” online: 〈https:/www.dpr.go.id/berita/ detail/id/26098/t/Isu+Gender+Akan+Diperjuangkan>.

6 Parliaments and legislative bodies are core actors in realizing the gender equality agenda in their capacity as lawmakers, oversight bodies, and employers. As representatives of the people, parliaments are expected to reflect the wishes and needs of the women and men they represent and ensure that all policies, including legislation, promote their interests. Ensuring equal opportunities for women and men, girls and boys fully realize their potential requires that parliaments and legislatures themselves model and advance gender-sensitivity in all processes, practices, and procedures. Tatyana Teplova, et al., OECD Toolkit for Mainstreaming and Implementing Gender Equality, Implementing the 2015 OECD Recommendation on Gender Equality in Public Life. Gender and Inclusiveness Unit, OECD (2015) at 49.
} 
to an extent, human rights. For example, in the 1945 Constitution, Article 28D (1) deals with the right to just and legal certainty, and Article $28 \mathrm{H}$ (2) relates to special treatment to obtain equal opportunities to achieve equality and justice. ${ }^{7}$ The following table is an overview of the Indonesian House in the period 2019-2024.

\section{Table 1}

Structure of Indonesia's House of Representative for the period 2019-2024 based on gender by its percentage

\begin{tabular}{|l|l|l|l|l|}
\hline Apparatus & Male & Percentage & Women & Percentage \\
\hline Leadership & 5 & $100 \%$ & 0 & $0 \%$ \\
\hline Budget Board & 75 & $76 \%$ & 24 & $24 \%$ \\
\hline Legislation Body & 58 & $76 \%$ & 18 & $24 \%$ \\
\hline Domestic Affairs Agency & 11 & $58 \%$ & 8 & $42 \%$ \\
\hline Inter-Parliamentary Cooperation Agency (BKSAP) & 39 & $74 \%$ & 14 & $26 \%$ \\
\hline State Financial Accountability Agency (BAKN) & 9 & $100 \%$ & 0 & $0 \%$ \\
\hline
\end{tabular}

Source : dpr.go.id

The Constitutional Court decided that priority to women's representation in the board's organs' leadership must be realized. However, it has not been accommodated in the latest Parliament Law, either Law Number 42 of 2014 or Law Number 2 of 2018. This study reveals the role of political regulation in Indonesia in accommodating gender equality and justice. Therefore, this study examines the extent to which the political sector legislations, particularly the Political Parties Law, the Election Law, and the Parliament Law, consider gender to provide a more just and fair opportunity for women. By using a gender justice and equality approach, it is expected to answer whether the existing legislations in the political sector have implemented gender justice and equality.

\section{GENDER AND GENDER EQUALITY IN INDONESIA'S LEGISLATION ON POLITICS}

\section{A. The Concept of Gender and Gender Equality}

The term gender was first introduced by Robert Stoller (1968). It was developed by Ann Oakley that stated gender is parallel to the biological division of sex into men and women. However, it does involve a social division and assessment of masculinity and femininity. In other words, gender is a concept that humans create socially, through interactions with each other and their environment, but is highly dependent on biological differences between men and women. Because humans create the concept of gender socially, gender refers to as social construction. ${ }^{8}$ Apart from Oakley, Scott

7 I Putu Oka Pratiwi Widasmara, "Pengaturan Terhadap Keterwakilan Perempuan dalam UndangUndang tentang MPR, DPR, DPD, dan DPRD ditinjau Berdasarkan Putusan Mahkamah Konstitusi Nomor 82/PUU-XII/ 2014" (2016) Udayana Master Law Journal 5:2 at 299.

8 Gender parallels the biological division of sex into male and female. However, it involves the division and social valuation of masculinity and femininity. In other words, gender is a concept that humans 
Coltrane stated that gender is built-in individual, interactional, and structural ways to create environmental constraints and opportunities that usually benefit men more than women. ${ }^{9}$ Meanwhile, the concept of gender, according to Mansour Fakih, is a trait inherent in both men and women that is constructed socially and culturally. For example, women are known to be gentle, beautiful, emotional, and motherly. In comparison, men are considered: strong, rational, manly, and mighty. The characteristics of nature itself are interchangeable traits. ${ }^{10}$ Thus, gender is identical to social differences in behavior, which can change over time. Gender is a social construction that can change and is not innate like sex. However, gender is relative and prioritizes equality between men and women in it. Gender equality is one way to realize democratization because gender equality opens opportunities and allows all people to participate in democracy. ${ }^{11}$ However, in reality, there are still many practices of gender injustice against women. Gender equality becomes the equal conditions for men and women to obtain opportunities and rights as human beings, to be able to play a role and participate in political, economic, social, cultural, defense, and national security activities, and to enjoy equality in enjoying the results of development. ${ }^{12}$

In Europe, in this concept of gender equality, everyone, whether a man or a woman, must be involved in all decision-making actions. Jahan calls it the agenda-setting approach, based on how gender prioritizes women's participation in making; in every decision, women participate in all development decisions and, through this process, bring about a fundamental change in the existing development paradigm. ${ }^{13}$ However, this application is not as easy as expected, even in areas where the government is as advanced as mainland Europe. The Council for Europe states that if gender equality is achieved, then there is a need for the (re)organization, improvement, development, and evaluation of policy processes. Thus, a gender equality perspective is incorporated in all policies at all levels by the actors typically involved in policy-making. ${ }^{14}$ It shows that changes in rules and policies become essential for achieving gender equality. As a result, the phrase

create socially, through their interactions with one another and their environments. However, it relies heavily upon biological differences between males and females. Because humans create the concept of gender socially, gender is referred to as a social construction. Ann Oakley, Sex, Gender, and Society (New York: Harper and Row, 1972).

9 Gender is constructed in individual, interactional, and structural ways to create environmental constraints and opportunities that usually benefit men more than women. Scott Coltrane, Gender and Families (CA: Pine Forge, CA, 1998).

10 Mansour Fakih, Analisis Gender dan Transformasi Sosial (Yogyakarta: Pustaka Pelajar, 2010) at 7.

ll Santi Wijaya Hesti Utami, Kesetaraan Gender, Langkah menuju Demokratisasi Desa (Yogyakarta: IP4: LAPPERA dan Asia Foundation, 2001).

12 Kunthi Tridewiyanti, 'Kesetaraan dan Keadilan Gender di Bidang Politik "Pentingnya Partisipasi dan Keterwakilan Perempuan di Legislatif” (2012) Jurnal Legislasi Indonesia 9:1 at 77.

13 Rounad Jahan, The Elusive Agenda: Mainstreaming Women in Development (London: Zed Books, 1995) at 15. Wanita berpartisipasi dalam semua keputusan pembangunan dan lewat proses ini diharapkan dapat membawa perubahan mendasar dalam paradigma pembangunan yang sudah ada.

14 Council of Europe, Committee of Ministers, Recommendation No. R (98) 14 of the Committee of Ministers to the Member States on Gender Mainstreaming, (1998). It was adopted by the Committee of Ministers on October 71998 at the $63^{\text {rd }}$ meeting of the Ministers' Deputies. There was a need for reorganization, improvement, development, and evaluation of policies. Then a gender equality perspective can be included at all levels and all stages involved in policy-making. 
'women's representation' can be fulfilled by paying attention to women's participation. Changes will slowly occur in government organizations, and the rules and policies issued will also benefit women. In contrast, Women often become those discriminated against by rules or policies that do not have women's voice in decision making.

\section{B. Gender Equality and Justice in Legislation}

Law Number 12 of 2011 on Legislative Drafting, in Article 6 (1), outlines the core substance of laws and regulations in Indonesia that should meet justice and equality. ${ }^{15}$ In its commentary, justice means that laws and regulations must reflect justice proportionally for every citizen without exception. In contrast, equality means an equal position in law and government, which may not contain discrimination based on religion, ethnicity, race, class, gender, or social status. It means that, principally, Indonesia's legislation should recognize gender equality. ${ }^{16}$ Also, it affirms that the formation of law in Indonesia must pay attention to aspects related to gender, especially women's rights. Insofar, it is contradictory because many regulations do not accommodate the protection of women's rights from all forms of discrimination. In fact. Indonesia ratified the Convention on the Elimination of All Forms of Discrimination Against Women (CEDAW) in Law Number 7 of 1984.

The indicators used to determine gender equality in the formation of legislation are access, participation, control, and benefits, or so-called Akses, Partisipasi, Kontrol dan Manfaat or APKM. Access relates to knowing whether there are equal opportunities for men and women for every resource that will be regulated in laws and regulations so that legal norms formulated reflect gender justice and equality. ${ }^{17}$ Participation means ensuring that laws and regulations provide equal opportunities to participate for men and women to exercise their rights and obligations in every development policy and program. ${ }^{18}$ Control means analyzing whether the legal norms formulated in statutory regulations contain equal provisions about men and women's power relations to exercise their rights and obligations. ${ }^{19}$ Benefit means an analysis of whether the formulated legal norms can guarantee that a policy or program will produce equal benefits for men and women in the future. ${ }^{20}$

Some principal issues concerning gender-sensitive lawmaking in parliament are the degree to which the institution exercises its initiative in legislating gender-sensitive laws and policies and the degree to which it influences the passage of gender-sensitive legislative proposals received from the executive. The underlying reality making gendersensitive lawmaking necessary is that we live in a society where women and men follow different life paths and have different living conditions and needs. Because of this,

15 Law No. 12 of 2011 on Legislative Drafting.

16 Sasmita, Parameter Kesetaraan Gender dalam Pembentukan Peraturan Perundang-undangan (2012) Jurnal Legislasi Indonesia 9:1 at 34.

17 Ibid at 34-36.

18 Ibid.

19 Ibid.

20 Ibid. 
societal rules and laws will affect men and women differently. Therefore, MPs must ensure that a gender perspective is integrated into all proposed legislation, policy formulation, and review. ${ }^{21}$ From the above statement, it is known that the initiation, innovation, and sensitivity of legislators are needed in proposing gender-sensitive arrangements and can understand the different situations between men and women so that social rules and laws will affect men and women differently as well. Through the substance of statutory regulations, it is expected that the law is a means of achieving prosperity and can create justice and benefit for the community, both men and women. ${ }^{22}$

\section{Principle of substantive equality}

Substantive equality considers and focuses on diversity, difference, disadvantage, and discrimination. This approach recognizes the differences between men and women by nature. This approach seeks to develop women's different treatment to catch up with their backwardness due to past differences and those experienced in the family and society. This substantive approach seeks to eliminate discrimination suffered by marginalized groups, individuals, institutions, and systems through corrective and positive actions. ${ }^{23}$

\section{Principles of non-discrimination}

The term discrimination against women means any discrimination, exclusion, or restriction made based on sex that has the effect or purpose of preventing or eliminating the recognition, enjoyment, or exercise of human rights and fundamental freedoms in the political, economic sphere. Social, cultural, civil, or anything else by women, regardless of their marital status, based on equality between women and men. Article 1 of the CEDAW Convention can be used to identify weaknesses in Legislation and formal or neutral policies. ${ }^{24}$

\section{Principle of state obligations}

According to the CEDAW Convention, State Obligations' basic principles include guaranteeing women's rights through law, legislation, and policies and guaranteeing the results. Ensure this right's practical exercise through measures or special temporary rules, creating a conducive environment to increase women's opportunities and access to existing opportunities. The state not only guarantees but also realizes women's rights. Not only guarantee de-jure but also de-facto. The state must be accountable, regulate it in the public sphere and the private sphere (family), and the private sector. ${ }^{25}$

21 National Democratic Institute for International Affairs, Round Table Discussion: Analyzing Legislation with a Gender Perspective (Assembly of the Republic of Macedonia, 2007) at 1.

22 Ministry of Law and Human Rights, Ministry of Women's Empowerment and Child Protection, Ministry of Home Affairs, Parameter Kesetaraan Gender dalam Pembentukan Peraturan PerundangUndangan (2011) at 2.

23 Ibid at 26

24 Ibid at 28.

25 Ibid. 


\section{GENDER ANALYSIS IN POLITICAL LEGISLATIONS}

Further details regarding gender analysis in the Political Parties Law, Election Law, and Parliament Law are provided below.

\section{Table 2}

Gender Analysis In the Political Parties Law, Election Law, and Parliament Law

\begin{tabular}{|c|c|c|}
\hline Law Political Party & Law General Election & Law Parliamentary Law \\
\hline \multicolumn{3}{|c|}{$\begin{array}{l}\text { Indicators: Access } \\
\text { - equal opportunities for men and women. } \\
\text { - regeneration system. } \\
\text { - political education. } \\
\text { - recruitment requirements to meet, especially for women in villages. }\end{array}$} \\
\hline $\begin{array}{l}\text { Establishment and } \\
\text { formation of political } \\
\text { parties. } \\
\text { System regeneration. } \\
\text { - One of the political parties' } \\
\text { functions is political } \\
\text { recruitment in filling } \\
\text { political positions through } \\
\text { democratic mechanisms, } \\
\text { paying attention to gender } \\
\text { equality and justice. } \\
\text { paying attention to gender } \\
\text { justice in the } \\
\text { implementation of political } \\
\text { education. }\end{array}$ & $\begin{array}{l}\text { There is no access when one of the requirements is } \\
\text { to become a candidate electoral staff from regency or } \\
\text { city to sub-village levels. The ballot supervisors are } \\
\text { with a minimum education of high school or } \\
\text { equivalent. How about for girls? Especially, at the } \\
\text { sub-village level. } \\
\text { Is the open proportional system more profitable for } \\
\text { female candidates? } \\
\text { Women's access to political parties. Political } \\
\text { parties can participate in elections after fulfilling } \\
\text { the requirements, including at least } 30 \% \text { women's } \\
\text { representation in the management of the central } \\
\text { political party. }{ }^{26} \text { It has not considered women's } \\
\text { access, especially for the District House of } \\
\text { Representatives regarding the minimum } \\
\text { requirements for education and willingness to } \\
\text { work full time. } \\
\text { Determining the ballot location easily accessible, } \\
\text { including for persons with disabilities, does not } \\
\text { combine villages, considers geographical aspects, } \\
\text { and ensures that each voter can cast their votes } \\
\text { directly, freely, and confidentially. No mentioned } \\
\text { locations easily accessible to women. }{ }^{27} \\
\text { Not yet providing gender-disaggregated data. }\end{array}$ & $\begin{array}{l}\text { The consideration section } \\
\text { contains the implementation } \\
\text { of people's sovereignty, which } \\
\text { embodies democratic values } \\
\text { and absorbs and fights for the } \\
\text { people and regions' } \\
\text { aspirations according to the } \\
\text { demands of the nation's life } \\
\text { and state. This provision } \\
\text { provides an opportunity to } \\
\text { fulfill society's needs, } \\
\text { including women, as long as it } \\
\text { is concretized in the torso. } \\
\text { However, this provision does } \\
\text { not yet provide a precise } \\
\text { formulation of mechanisms } \\
\text { and indicators. } \\
\text { - The meeting at the House is } \\
\text { open in nature. It is not clear } \\
\text { about the mechanism and } \\
\text { procedure mechanism. }{ }^{28} \\
\text { - The selecting House's } \\
\text { structure and the member } \\
\text { recall do not provide access to } \\
\text { women's representation. }\end{array}$ \\
\hline \multicolumn{3}{|c|}{$\begin{array}{l}\text { Indicators: Participation } \\
\text { Recruitment and women's representation }\end{array}$} \\
\hline $\begin{array}{l}\text { Recruitment of party } \\
\text { members, candidates for } \\
\text { the House and the Regional } \\
\text { House, candidates for } \\
\text { regional head and deputy } \\
\text { regional head, and } \\
\text { candidates for President } \\
\text { and Vice President are }\end{array}$ & $\begin{array}{l}\text { It is mandatory to consider women's } \\
\text { representation at least 30\% for the composition of: } \\
\text { 1) The Election Commission membership at the } \\
\text { central, provincial, and district/city levels. } \\
\text { 2) Sub-district Electoral Committee membership. } \\
\text { 3) Ballot Box Committee membership at the } \\
\text { village level. } \\
\text { 4) Voting Organizing Group membership. }\end{array}$ & $\begin{array}{l}\text { There is no provision to } \\
\text { consider women's } \\
\text { representation in the People's } \\
\text { Consultative Assembly } \\
\text { leadership and ad hoc } \\
\text { committees. } \\
\text { The removal of the phrase, "by } \\
\text { taking into account women }\end{array}$ \\
\hline
\end{tabular}

26 Consider notes provided by Sarah Bibler, Vasu Mohan, and Katie Ryan, Gender Equality and Electoral Administration: A Guide to Best Practice (International Foundation for Electoral Systems) at 8-9.

27 Ibid, at 9.

28 Open access to the public is not always open to women due to various inhibiting factors that reduce women's opportunities to access information and opportunities the same as men. Ibid. 
carried out democratically per the statutes and bylaws most at least 30\% female representation.
However, there is no requirement for women's representation in the Election Supervisory Agency's membership at the central, provincial, and district/city levels. What about Overseas Election Committee, Overseas Voting Organizing Group, and General Election Organizer Honorary Council. representation in the House" in the formation of:

1. Commission. ${ }^{29}$

2. Legislation Body. ${ }^{30}$

3. Budget Agency. ${ }^{31}$

4. State Financial Accountability Agency. ${ }^{32}$

5. Inter-Parliamentary Cooperation Agency. ${ }^{33}$

6. Special Committee. ${ }^{34}$

7. Honorary Agency. ${ }^{35}$

8. Domestic Affairs Agency. ${ }^{36}$

Indicator: Control

-Strategic position in decision making.

-Systematic and consistent.

The legal basis section does - The absence of Article $28 \mathrm{H} \mathrm{(2).}$

not include Article $28 \mathrm{H}$

(2), Article 2 (5), and Article 20 regarding political parties' management at the central and regional levels.
The selection team's membership to assist the President in determining the Election Commission member candidates to be submitted to the House with a maximum of 11 members with special women's representation at least 30\%.

Political parties can participate in elections after fulfilling the requirements, including at least 30\% of women's representation in the central political party.

One of the documents a political party should fulfill to register as an eligible participant is a statement from the political party's central management regarding the inclusion of women's representation at least 30\% per the legislation. Cohesiveness is one of the principles preparing electoral districts; the list of candidate candidates for the House, Regional Representative, and Regional House must contain at least 30\% women's representation for each candidate for the House, Regional Representatives, and Regional House candidates in each electoral district, every three candidate candidates must include at least one female candidate in it.

The Election Commission must verify the list of prospective candidates for the House, Regional

29 Compare to Article 95 (2) that regulates the previous Parliament Law (Law No. 27 of 2009) which stated the formation of a commission in the House whose leadership consists of one chairman and a maximum of three a deputy chairperson who is elected from and by members of the commission based on the principle of deliberation to reach a consensus by taking into account women's representation according to the consideration of the number of members of each faction.

30 Compare to Article 101 (2) of Law No. 27 of 2009.

31 Compare to Article 106 (2) of Law No. 27 of 2009.

32 Compare to Article 132 (2) of Law No. 27 of 2009.

33 Compare to Article 119 (2) of Law No. 27 of 2009.

34 Compare to Article 138 (2) of Law No. 27 of 2009.

35 Compare to Article 125 (2) of Law No. 27 of 2009.

36 Compare to Article 132 (2) of Law No. 27 of 2009. 
Indicator: Benefits

Representative, and Regional House to meet women's representation of at least 30\%.

Suppose the House, Regional Representative, and

Regional House candidates do not meet women's representation at least 30\%. In that case, the Election Commission requires them to include women for candidacy.

The Election Commission must announce the percentage of women's representation in the provisional list of candidates for each political party in the national daily printed mass media and the national electronic mass media.

The Election Commission must announce the percentage of women's representation in the final list of candidates for each political party in the national daily printed mass media and the national electronic mass media.

The Constitutional Court Decisions No. 22-24 of $2008^{37}$ and No. 20 of $2013^{38}$ promote affirmative policies in this Law.

Can regulations assure that women and men can receive benefits fairly?

It can be seen from the precise mechanism \& the existence of sanctions.

- Administrative sanctions in The number of seats for the Provincial and Regency the form of refusal of House (Regional House) only refers to the registration of political population, not the area's sociological and parties as legal entities by the geographical conditions.

There is no harmonization effort made by the government after the Constitutional Court Decision No 82/2014.

Department for violations of

Article 2. However, there is no sanction for violations of Articles 20 and 29 (la).

There are no further provisions regarding the provisions of Articles 11 (1) and 31.

From the table above, the Political Parties Law is sufficient to accommodate and pay attention to women's representation in it, both in terms of access, participation, control, and benefits. Meanwhile, the Election Law still has to dissect how overseas polling station supervisors have yet to consider women's representatives in it. Finally, the Parliament Law is miserable that it has not yet followed the Constitutional Court's Decision No. 22-24/PUU-VI/2008 that requires a priority or necessity to pay attention

37 A 30\% quota and one female candidate's obligation out of every three candidates constitutes positive discrimination that balances the gender representation to become legislators in the House, the Regional Representative, and the Regional House. The provision of a 30\% quota for female candidates is confirmed by Article 54 (2) of Law 10 of 2008 so that it guarantees to provide more significant opportunities for women's electability in general elections.

38 Legal considerations for point 10 is whereas, concerning the Constitutional Court Decision Number 22-24/PUU-VI/2008, the Court should reaffirm a 30\% quota and the obligation to have at least one female candidate out of every three prospective candidates constitutes positive discrimination to guarantee more significant opportunities for women's electability in a general election in order to balance the representation of women and men to become members of the House, the Regional Representative, and the Regional House. 
to women's representatives in the legislative body, especially in strategic positions in the field of budgeting because it will also affect gender policies which later issued by the government.

\section{A. Access, Participation, Control and Benefits of Political Parties}

Political Parties Law sufficiently accommodate gender needs since the beginning of the formulation. It refers to the academic manuscripts and documents compiling an inventory of the draft political parties bill..$^{39}$ As an example of the table above, the Political Parties Law provides access to gender equality and justice to establish and form political parties, the cadre system, political recruitment, and regeneration. Regarding participation, the recruitment of political parties, the House and the Regional House candidates, regional head candidates, and presidential and vice-presidential candidates will be carried out democratically according to Articles of Incorporation by considering at least 30\% women's representation. However, this provision remains questionable from the control aspect because it is left to the party's Articles of Incorporation's internal mechanism. It is worth appreciating the provisions of Articles 2 (5) and 20, which consider the $30 \%$ women's representation in the management of central and regional political parties.

\section{B. Access, Participation, Control and Benefits of Election Law}

In the Election Law, in terms of access, it does not provide access to women regarding the requirements to become candidates for members of the election supervisory agencies at the regency or city level, sub-district level, village level, and ballot box level. It also does not require to possess at least high school or equivalent. It becomes an obstacle for women, especially at the village level. The open proportional system also raises the question of whether it will be more profitable for female candidates. Has not considered women's access, especially for the district House of Representatives regarding the minimum requirements for education and willingness to work full time. The involvement during the election implementation also needs to be considered, for example, determining the location of polling stations that are easily accessible, including for persons with disabilities, not combining villages, and paying attention to geographical aspects, and ensuring that each voter can vote directly, freely and confidentially. Another obstacle for women in terms of access is that there is no mention of locations that are easily accessible to women. ${ }^{40}$ And it has not provided data disaggregated by gender.

On the other hand, women's access to political parties is more open because one of the requirements for political parties to participate in elections after fulfilling the requirements is to include at least 30\% women's representation in central political

39 The House of Representatives, Dokumen Utama Daftar Inventarisasi Masalah (DIM) Rancangan Undang-Undang (RUU) tentang Partai Politik 12 September 2007, online: 〈https://parlemen.net/wpcontent/uploads/2016/05/RUU-Partai-Politik-DIM-RUU-Parpol-ttg-Keterwakilan-Perempuan-olehPuskapol-Fisip-UI-19Sept07.pdf>.

40 Sarah Bibler, Vasu Mohan dan Katie Ryan, supra note 26 at 9. 
parties' management. ${ }^{41}$ Consideration of women's access needs to be considered because of a woman's dual role, and according to the International Labor Organization (ILO). One barrier to women's political participation and leadership is time use. Spend up to four times more time on unpaid care than men in the region, precluding them from economic and political participation. ${ }^{42}$ However, participation in the Election Law is sufficiently accommodated concerning the composition rules regarding membership for the Election Commission, Sub-district Electoral Committee, Ballot Box Committee, Voting Organizing Group, and the Election Supervisory Agency must consider at least 30\% women's representation. Unfortunately, Overseas Election Committee, Overseas Voting Organizing Group, and General Election Organizer Honorary Council do not require women's representation.

The control aspect in the Election Law is that the absence of Article 28H (2) of the 1945 Constitution, which mandates everybody has the right to get facilities and special treatment to get the same opportunities and benefits to achieve equal justice in the legal basis section. This article should be the basis for showing the seriousness of the government to provide equal opportunities for everyone regardless of ethnicity, race, religion, culture, or gender in their efforts to participate directly as a candidate for Parliament. Then, in this law, it is stated that the President will form a selection team consisting of a maximum of eleven members who will select the Election Commission member candidates with the provision of paying attention to women's representation at least 30\%. This regulation can also fall into the category of access and participation. However, the influence of the position given in this regulation can also be interpreted as a form of control over Election Commission members' election by considering women's opinions in every decision making. Besides, the provisions relating to a political party's requirements to participate in the General Election also show control indicators, namely on the condition to participate in a general election. A political party must meet women's representation of at least 30\% at the central management level. The document that should be attached to apply for registration as a participant in the general election is a statement from each political party's central management level. This statement should mention at least 30\% of women's representation in the central management of a political party has been fulfilled. This law also stipulates that there are principles applied in the preparation of electoral districts related to control. Thus, the application of the cohesiveness principle becomes one of the gender-sensitive principles. The definition of cohesiveness is a consideration based on historical aspects, customs, and minority groups in the preparation of electoral districts.

Another form of control is reflected in the submission of a list of candidates for the House, Regional Representative, and Regional House by every political party which must also pay attention to women's representation in their candidate list of at least 30\% and other requirements such as each list of candidates for the House, Regional

41 Ibid.

42 International Labour Organization (ILO), Women do four times more unpaid care work than men in Asia and the Pacific, June 27, 2018. 
Representative, and Regional House in each electoral district, every three prospective candidates must include at least one female candidate. This requirement is accompanied by the Election Commission's authority to verify the requirements related to women's representation in the list of candidates for the House, Regional Representative, and Regional House candidates are fulfilled. If these conditions are not met, then the Election Commission will provide opportunities for political parties to improve the list of prospective members so that women's representation of at least $30 \%$ is fulfilled.

Announcements relating to the percentage of women's representation in the provisional and permanent list of candidates for the House, Regional Representative, and Regional House from each political party must also be submitted by Election Commission in the national daily printed mass media and national electronic mass media so that the public can know the number of women's representation in the nomination of members of the House, Regional Representative, and Regional House before the election.

The policy of implementing the $30 \%$ quota is quick affirmative action. This is a form of positive discrimination for women to encourage more women's participation in the political field. This policy is implemented based on a ratification of the CEDAW Convention and based on the Constitutional Court Decision No. 22-24/PUU-VI/2008 regarding the review of Law 10/2008 on the General Elections for the House, Regional Representative, and Regional House against the 1945 Constitution. It applied a 30\% quota of women's representation in legislative candidates. One woman in every three candidates is deemed to have fulfilled the purpose of the affirmative action in CEDAW. ${ }^{43}$ Other Constitutional Court decisions such as Decision No. 20/PUU-XI/2013 reinforce the policy of implementing this $30 \%$ quota by stating that the phrase "consider" must be interpreted as "prioritizing" female candidates if the distribution of votes obtained by male and female candidates is broadly considered to have more actual meaning and is more serious in reckoning to women's representation. ${ }^{44}$

From the benefit aspect, the determination of the number of seats in the Regional House at both the provincial and district/city levels is based on the allocation of electoral districts based on the population, which seems like a gender-insensitive rule because there are no other considerations in it. Such considerations are based on the sociological or geographic conditions of an area, for example, areas dominated by women or areas with geographic conditions that prevent travel access to polling stations and other considerations.

\section{Access, Participation, Control, and Benefits of the Parliament Law}

In connection with the access in the Parliament Law, the guarantee has been illustrated in the weighing section, which states that to exercise people's sovereignty on a widespread basis led by wisdom in representation, it is necessary realizing people's consultative institutions, people's representative institutions and regional representative institutions that can embody democratic values and absorb and fight for

43 Constitutional Court Decision No. 22-24/PUU-VI/2008.

44 Constitutional Court Decision No. 20/PUU-XI/2013. 
the aspirations of the people and regions following the demands of the development of the life of the nation and state. The sound of the considering part can be said to be a form of the seriousness of the government that there is a guarantee for everyone regardless of gender, that whoever has the right to have their needs met during the life of the nation and state through aspirations conveyed through the intermediary of representative institutions. This goes on as long as this part of the consideration becomes a substantial part of the Parliament Law and is even confirmed by the contents of the body of this Law, for example, the provisions in Article 5 which mention the duties of the People's Consultative Assembly and Article 9 which contains the oaths/promises made by the people's representatives in carrying out his position. However, in reality, there is still no clarity regarding meeting these needs and the ease of access to parliament.

Regarding other forms of access, one of which is the holding of the House meetings. All the House meetings are open, except for certain meetings that are declared closed. However, this is also constrained by access for some groups such as customary law communities, other minority groups, including women's groups, because women's abilities are not the same as men with various factors accompanying women so that there are many difficulties in accessing political-based activities such as the House meetings. There is the involvement of gender roles in it, which results in low civil and political awareness in women, stereotypes that emerge such as zero-sum games where whether involved or not, women's opinions are considered not very influential. This will also indirectly limited public support for women who try to be involved in political activities. $^{45}$

Based on the principles of good governance Regarding access, it should be guaranteed because public information is one of the human rights that is regulated constitutionally in Article 28F of the 1945 Constitution of the Republic of Indonesia to guarantee the right of everyone to communicate and obtain information in order to develop their own personal and social environment. ${ }^{46}$ It includes information and easy access to the results of the House meetings for women's groups.

Other access limitations also arise from the mechanism for selecting the Apparatus of the House and its member recall, ${ }^{47}$ which is not gender-sensitive because there are no regulations that state the obligation to pay attention to women's representation. The participation share is the indicator part that needs the most attention in the Parliament Law. This is due to the massive changes from the provisions in Law Number 27 of 2009 to Law Number 17 of 2014, namely the elimination of every phrase "considering women's representation" in the selection of strategic positions or leadership either at the MPR Chair, the ad hoc committee, the Commission Chair, the Head of the Legislative Body, the Head of the Budget Committee, Head of the State Financial Accountability Agency,

45 Sarah Bibler, Vasu Mohan, and Katie Ryan, supra note 26 at 9.

46 Adam Muhshi, "Pemenuhan Hak atas Informasi Publik sebagai Tanggung Jawab Negara dalam Mewujudkan Good Governance" (2018) Lentera Hukum 5:1 at 68.

47 Jayus, Muhammad Bahrul Ulum \& Moch Marsa Taufiqurrohman, "Examining Recall of the House Member: How Does It Impact on Eradicating Corruption in Indonesia?" (2020) Lentera Hukum, 7:1 at 104. 
Chair of the Inter-Parliamentary Cooperation Agency, Chair of the Special Committee, Chair of the Honorary Agency, and the Head of the Household Affairs Agency. It directly eliminates the need to consider women's representation in the mechanism for filling strategic positions, which will later also be related to control measures in measuring gender justice and equality in legislation.

This significant gap within the national and local governments hinders Millennium Development Goals (MDGs). These MDGs requires the government for women's empowerment. Therefore, as a regulation closely related to politics, the Parliament Law can ensure equal rights for women by strengthening regulation and implementation and monitoring, which will be more effective in addressing women's institutional and sociocultural challenges. ${ }^{48}$

The control aspect in the Parliament Law states that the House as a people's representative institution carries out legislative, budgeting, and supervisory functions which will be carried out within the framework of people's representation, and also to support the government's efforts in implementing foreign policy under the provisions of laws and regulations. Unfortunately, this arrangement is a gender-neutral arrangement. It is increasingly being disrupted by the elimination of the consideration of "women's representation" in the selection of the House's structure, which is a strategic position for women so that there is no adequate control in making any decisions or making policies there is no legal certainty whether there have been considerations related to justice and gender equality in it.

The presence of women in parliament as the House's structure is essential for gender mainstreaming in the council's three functions: legislation, budget, and oversight. The goal of women's presence in parliament to produce equal and fair legislation products can be more certain. ${ }^{49}$ Gender mainstreaming has even been mandated since Presidential Instruction Number 9 of 2000 on Gender Mainstreaming in National Development, which aims to reduce the gap between women and men in Indonesia in accessing and obtaining the benefits of development in terms of mastery of the development process. ${ }^{50}$

There is a legal gap at the implementation level, especially between the existing laws and regulations and the government's realities. ${ }^{51}$ It is solely because there is no statutory regulation that is truly perfect. There must be limitations and shortcomings.

48 Ministry of Women's Empowerment and Child Protection, together with the Ministry of National Development Planning/National Development Planning Agency. Policy Paper: Gender Equality.

49 Usep Hasan Sadikin, Pengarusutamaan Gender dalam UU MD3, (2020), online: 〈https://rumahpemilu.org/ pengarusutamaan-gender-dalam-uu-md3/〉.

50 Ministry of Women's Empowerment and Child Protection and the Ministry Planning of National Development/National Development Planning Agency, supra note 48 at 1.

51 The potential for irregularities in the law creates a so-called legal gap. The gaps or lacunae that occur proceed through simple patterns. The process begins with the availability of favorable laws waiting to be activated through contact with concrete events. When this contact occurs, there is a possibility that positive law is not able to answer needs in concrete events correctly. Sidharta, Pendekatan Hukum Progresif Dalam Mencairkan Kebekuan Produk Legislasi, dalam Dekonstruksi dan Gerakan Pemikiran Hukum Progresif (Thafa Media, 2013) at 27. 
No law can regulate the entire human activity without exception. ${ }^{52}$ According to Sidharta, positive law as a legal product is always perceived as recording a portrait of society only in a certain period (synchronous). The portrait results show that the legal system is a momentary legal system. On the other hand, whether people realize it or not, they will end up changes in the process while legal products tend to crystallize. ${ }^{53}$

One of the considerations in this decision is that the Parliament Law is deemed unable to provide legal certainty, especially for women's groups due to the elimination of the phrase "women's representation" and its substance in Articles 97 (2), 104 (2), 109 (2), 115 (2), 121 (2), 152 (2), and 158 (2) are deemed contrary to the constitutional rights granted by the 1945 Constitution as stated in Articles 28D (1), 28H (2) and 28J (2). It is decided that the provisions in the article being tested are contrary to the provisions of the 1945 Constitution and do not have binding legal force as long as it does not mean that there is a need to pay attention to women's representation in the appointment of the leadership of the House apparatus. ${ }^{54}$ Nevertheless, even with three revisions to the Parliament Law, there is still no legal harmonization under the Constitutional Court Decision No. 82/PUU/XII/2014. Therefore, Parliament Law cannot accommodate gender justice and equality in its regulations.

\section{CONCLUSION}

Gender-responsive legislation is not just a policy that includes women's representation in a position. Instead, it needs to accommodate women's problems and place women in that position and adequately carry out their functions. The laws and regulations in the field of politics in Indonesia, especially the Political Parties Law, the Election Law, and the Parliament Law, are still not optimal, especially for the control benefits indicators. This analysis refers to the justice and gender equality approach. Among the three laws in the political arena, the Parliament Law is the one that at least provides space for women, both in terms of access, participation, control, and benefits. If analyzed using a gender approach, legislation in the political sector is the law on political parties. It contributes more to the indicators of access. While the election law to the indicators of access and participation, the Parliament law is expected to contribute the most to control and benefits indicators. Unfortunately, Parliament Law did not fulfill both indicators. As the guardian of the constitution in several judicial review decisions of political laws, the Constitutional Court has exercised control that strengthens women's representation in the political field but has not been acted upon by legislators in the amendment of the law in question.

Affirmative policy in the revision of the Law on Political Parties, Elections and Parliament should encourage the benefit of social life that is more just, non-

52 Sadhu Bagas Suratno, "Pembentukan Peraturan Kebijakan Berdasarkan Asas-Asas Umum Pemerintahan yang Baik" (2017) Lentera Hukum 4:3 at 166.

53 Sidharta, supra note 52 at 27-28.

54 Constitutional Court Decision No. 82/PUU/XII/2014. 
discriminatory and provides equal opportunities for every citizen to access rights and benefits in development. Women's political representation needs to be accompanied by consistent political empowerment supported by a women's leadership model, political training programs for women starting from political parties, collaborating with related civilian organizations or community organizations, and visibility in the media. The need for the state's commitment to gender mainstreaming in policy, harmonization, and synchronization of laws and regulations, including harmonization or synchronization implemented by the Ministry of Law and Human Rights and follow-up to the results of the Constitutional Court decisions. Thus, the need for a more in-depth gender study and socio-legal studies at every stage of legislative formation in the political field and other fields.

\section{ACKNOWLEDGMENTS}

None.

\section{COMPETING INTERESTS}

The authors declare that they have no competing interests.

\section{REFERENCES}

Adam Muhshi. Pemenuhan Hak atas Informasi Publik sebagai Tanggung Jawab Negara dalam Mewujudkan Good Governance. (2018) 5:1 Lentera Hukum.

Ann Oakley. Sex, Gender, and Society (New York: Harper and Row, 1972).

Bibler, Sarah, Mohan, Vasu dan Ryan, Katie. Kesetaraan Gender dan Penyelenggaraan Pemilu: Panduan Praktek Terbaik (International Foundation for Electoral System). Council of Europe, Committee of Ministers. Recommendation No. R (98) 14 of the Committee of Ministers to the Member States on Gender Mainstreaming. Adopted by the Committee of Ministers on October 7, 1998, at the 643rd meeting of the Ministers' Deputies.

Erlina. Implementasi Hak Konstitusional Perempuan dalam Peraturan Perundangundangan di Indonesia (2012) 1:1 Jurnal Konstitusi.

Fakih, Mansour. Analisis Gender dan Transformasi Sosial (Yogyakarta: Pustaka Pelajar, 2010).

House of Representatives. "Dokumen Utama Daftar Inventarisasi Masalah (DIM) Rancangan Undang-Undang (RUU) tentang Partai Politik Tanggal 12 September 2007" (2020) online: 〈https://parlemen.net/wp-content/uploads/2016/05/RUUPartai-Politik-DIM-RUU-Parpol-ttg-Keterwakilan-Perempuan-oleh-PuskapolFisip-UI-19Sept07.pdf>. 
"Isu Gender Akan Diperjuangkan" online: 〈https://www. dpr.go.id/berita/detail/id/26098/t/Isu+Gender+Akan+Diperjuangkan〉.

I Putu Oka Pratiwi Widasmara. Pengaturan Terhadap Keterwakilan Perempuan dalam Undang-Undang tentang MPR, DPR, DPD, dan DPRD ditinjau Berdasarkan Putusan Mahkamah Konstitusi Nomor 82/PUU-XII/ 2014. (2016) 5:2 Udayana Master Law Journal.

International Labour Organization (ILO). Women do four times more unpaid care work than men in Asia and the Pacific (June 27, 2018).

Jahan, Rounad. The Elusive Agenda: Mainstreaming Women in Development (London: Zed Books, 1995).

Jayus, Muhammad Bahrul Ulum \& Moch Marsa Taufiqurrohman. Examining Recall of the House Member: How Does It Impact on Eradicating Corruption in Indonesia? (2020) 7:1 Lentera Hukum.

Kementerian Hukum dan Hak Asasi Manusia, Kementerian Pemberdayaan Perempuan dan Perlindugan Anak, Kementerian Dalam Negeri. Parameter Kesetaraan Gender dalam Pembentukan Peraturan Perundang-Undangan (Kemenkumham RI, 2011).

Kementerian Pemberdayaan Perempuan dan Perlindungan Anak bersama Kementerian Perencanaan Pembangunan Nasional/Badan Perancangan Pembangunan Nasional. (Kertas Kebijakan: Kesetaraan Gender).

Knut D. Asplund, et al. Hukum Hak Asasi Manusia (Yogyakarta: Pusham UII Yogyakarta, 2008).

Kunthi Tridewiyanti. Kesetaraan dan Keadilan Gender di Bidang Politik Pentingnya Partisipasi dan Keterwakilan Perempuan di Legislatif (2012) 9:1 Jurnal Legislasi Indonesia.

National Democratic Institute for International Affairs. Round Table Discussion: Analyzing Legislation with a Gender Perspective (Assembly of the Republic of Macedonia, 2007).

Sadhu Bagas Suratno. Pembentukan Peraturan Kebijakan Berdasarkan Asas-Asas Umum Pemerintahan yang Baik (2017) 4:3 Lentera Hukum.

Sadikin, Usep Hasan, Pengarusutamaan Gender dalam UU MD3 (2020), online: 〈https://rumahpemilu.org/pengarusutamaan-gender-dalam-uu-md3/>.

Santi Wijaya Hesti Utami. Kesetaraan Gender, Langkah menuju Demokratisasi Desa (Yogyakarta: IP4:LAPPERA dan Asia Foundation, 2001).

Sasmita. Parameter Kesetaraan Gender dalam Pembentukan Peraturan Perundangundangan (2011) 9:1 Jurnal Legislasi Indonesia.

Scott Coltrane. Gender and Families (Thousand Oaks, CA: Pine Forge, 1998).

Sidharta. Pendekatan Hukum Progresif Dalam Mencairkan Kebekuan Produk Legislasi, dalam Dekonstruksi dan Gerakan Pemikiran Hukum Progresif (Yogyakarta: Thafa Media, 2013).

Tatyana Teplova, et al. OECD Toolkit for Mainstreaming and Implementing Gender Equality, Implementing the 2015 OECD Recommendation on Gender Equality in Public Life (Gender and Inclusiveness Unit, OECD, 2015). 
Tirto.id, "Isi Kursi DPR 2019-2024, Porsi Perempuan Meningkat" online: 〈https://tirto.id /isi-kursi-dpr-2019-2024-porsi-perempuan-meningkat>.

World Economic Forum. Global Gender Gap Report 2020 (2019). 